\title{
THE BIG PICTURE
}

\section{Chinese premier rallies medics in coronavirus fight}

\author{
Tom Moberly
}

The BMJ

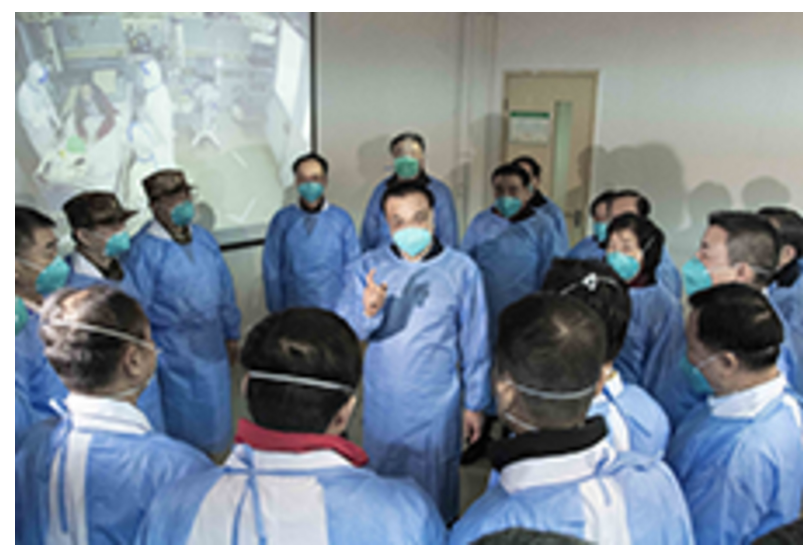

[Image: XinhualLi Tao/PA]

China's premier, Li Keqiang (centre), visited the Wuhan Jinyintan Hospital this week to see the team's work to control the outbreak of the novel coronavirus in the area.
$\mathrm{Li}$ arrived on 27 January to inspect and direct the prevention and control efforts and spoke to frontline medical workers at the hospital in Wuhan, central China's Hubei province. $\mathrm{Li}$ is head of a group of the Communist Party of China's Central Committee leading on the outbreak.

A report from Imperial College London warned this week that uncertainty over the severity spectrum of the coronavirus, and whether people with mild symptoms could efficiently transmit the virus, meant that it was currently "unclear" whether the outbreak could be contained within China. ${ }^{1}$

The researchers said that controlling the situation would require "successful detection, testing, and isolation of suspect cases with the broadest possible range of symptom severity," and they called for efforts in these areas to be as "extensive" as the capacity of health services allow.

Mahase E. China coronavirus: mild but infectious cases may make it hard to control outbreak, report warns. BMJ 2020;368:m32510.1136/bmj.m325.

Published by the BMJ Publishing Group Limited. For permission to use (where not already granted under a licence) please go to http://group.bmj.com/group/rights-licensing/ permissions 